\title{
Fidiana Fidiana
}

Departement of Accounting, Sekolah Tinggi Ilmu Ekonomi Indonesia Surabaya (email: fidiana@stiesia.ac.id)

Submitted: 18 October 2020, Revised: 1 May 2021, Accepted: 8 June 2021

Fidiana, Fidiana Lecturer and researcher in Accounting. She graduated from the Accounting Doctorate Program, Brawijaya University, Indonesia, in 2014, majoring in sharia accounting and taxation. Until now, she has worked as a lecturer and researcher at the Department of Accounting, Sekolah Tinggi IImu Ekonomi Indonesia Surabaya.
Policy \& Governance Review ISSN 2580-4820

Vol. 5, Issue 3, pp. 195-205

DOI: https://doi.org/10.30589/pgr. v5i3.373

\section{Tax Facilities through Omnibus Law Taxation: A Canon Taxation Review}

\begin{abstract}
This research is a conceptual study to examine tax policy in the pandemic situation with a canon taxation perspective, namely equity, certainty, convenience, and efficiency. The study conducted by using a literature review concerning the role of Omnibus Law includes tax facilities to attract foreign investment underlining strengths and weaknesses. Data is obtained through secondary sources in the form of archival reports and previous research relevant to the research. Based on the analysis of literature studies, this research produces several things. First, the principle of equity is found in adjusting corporate tax rates. Associated with the aim of attracting foreign investment, the tariff adjustment policy naturally will not be realized in 2020 , where traffic between countries is restricted to prevent the spread of Covid-19. Second, in the tax policy scheme of domestic tax subject reclassification, which includes more than 183 foreigners working in Indonesia, and Indonesian citizens living abroad over 183 days are classified as subject to foreign tax. Tax is imposed on foreigners only on income earned in Indonesia. This pattern fulfills certainty principles. Third, the regional tax incentive scheme is an instrument that ensures the certainty of regional investment in line with the principles of equity and convenience. Furthermore, local tax exemptions can lower the price of consumer goods in the regions, thereby increasing the purchasing power of the wider community, which was hampered by the pandemic. In this way, local taxes play a role in increasing regional competitiveness through public policies (tax incentives), to improve the welfare of people, especially those affected by the epidemic. Fourth, the tax holiday scheme encourages industrial growth in accordance with the principle of efficiency.
\end{abstract}

\section{Keywords:}

canon taxation; omnibus law; pandemic covid-19; taxation

\section{Introduction}

The issue of Corona

Virus Disease (Covid-19) has

had an impact on worldwide

taxation. Various countries have

launched tax relief policies (tax breaks) for taxpayers affected by the Coronavirus. The tax relief scheme was implemented for the first time in March 2020, spearheaded by Canada, Chile, China, The Czech Republic, 
Denmark, Iceland, Latvia, Poland, Turkey, Ukraine, The UK (Enache et al., 2020), and also followed by other countries around the world, including Germany (KPMG, 2020) and Indonesia on 20 March 2020.

The Indonesian government also issued a tax incentive policy through the omnibus law of taxation. One form of tax incentive implementation is to extend the tax reporting period to April 30, 2020, without imposing administrative penalties (Directorate General of Taxes, 2020a). Subsequently, the government issued a series of financial policies, including Government Regulation No. 1 of 2020 . This regulation contains state financial policies in the context of dealing with threats that could be dangerous to the stability of the financial system and the national economy (Directorate General of Taxes, 2020a).

The Government Regulation No. 1 of 2020 contains 4 (four) taxation policies, namely adjusting the income tax for domestic corporate taxpayers and permanent establishments, imposing taxes on trade transactions with electronic/digital systems, extending the time for implementing tax rights and obligations, and authorizing the Minister of Finance to exempt or provide relief from import duties in the context of restoring and strengthening the national economy, as well as dealing with emergency conditions.

Finally, a series of tax incentive policies were passed by the government through a taxation law omnibus policy summarized in the Job Creation Bill. This regulation is one of the tax reforms that evaluates tax previous policies that were considered less conducive to improving the investment climate in Indonesia. By implementing the policy, it is hoped to simplify so many rules in quantity (Directorate General of Taxes, 2020b). This tax reform is certainly carried out by evaluating previous policies that were deemed less conducive to improving the investment climate in Indonesia.

The omnibus law generally aims to strengthen the Indonesian economy and tax base through tax facilities aimed at increasing investment attractiveness, increasing equity and fairness in business, improving the quality of human resources, and increasing voluntary tax compliance (Directorate General of Taxes, 2020b). Omnibus law targets, among others, the elimination of income tax on dividends, lowering corporate income tax rates, adjusting the income tax rate on interest, setting tax facilities, imposing taxes on digital transactions and expatriate income taxes, and VAT crediting provisions.

In general, taxation omnibus law can be interpreted as a tax incentive scheme or fiscal stimulus launched by the government in order to attract foreign investment and expand the tax base. Fiscal stimulus schemes are widely applied in various countries, especially developing countries, with the assumption that taxes are considered as an indicator that determines the location of cross-country investment. In other words, cross-country investment decisions are influenced by the country's fiscal policies.

Fiscal stimulus strategies were developed globally in the early 1990s (Quan Li, 2006; Morisset, 2003; Revilla, 2016) and are used by developing countries that wish to improve the investment climate (Daude et al., 2017; Qun Li, 2008; Parys, 2012; Revilla, 2016; Thuita, 2017; Wiedemann \& Finke, 2015). However, various research results reject tax incentives as a means of increasing foreign direct investment (FDI) in developing countries (Fletcher, 2002; Parys, 2012; Thuita, 2017), Asean countries (Revilla, 2016), Asia Pacific (Megersa, 2019; Wiedemann \& Finke, 2015), China (Qun Li, 2008), Dominican Republic (Daude et al., 2017), and Africa (Boly et al., 2019).

These conditions encourage the investigation of the effectiveness of tax incentives initiated by the government through the taxation law omnibus policy package. This is important to do because several studies have reported that not all indicators of tax incentives are effective in increasing investment. Tax rates, according to 
several studies, have not succeeded in increasing foreign investment (Revilla, 2016; Stausholm, 2017; Thuita, 2017).

In fact, one of the omnibus law policy packages is a reduction in corporate tax rates. Several studies have suggested more political regime stability, legal certainty, infrastructure, and ease of tax administration as indicators of tax incentives as schemes that can improve the investment climate (Daude et al., 2017; Hadari, 1990; Quan Li, 2006; Parys, 2012; Revilla, 2016). Legal certainty, convenience, transparency, and political regimes are considered more effective in creating investment attractiveness. These aspects are actually indicators of a good tax system that was initiated by Adam Smith in 1976 (Smith, 1776). Adam Smith uses the term canon taxation which includes the principles of equity, certainty, convenience, and efficiency as the pillars of a good tax system. Various studies have agreed to make the taxation canon the parent of tax system development in the world.

It is important to study tax incentives summarized in the tax omnibus law so that it is in line with the government's hopes of increasing investment in Indonesia. This research will develop a study of the effectiveness of tax incentives summarized in the taxation omnibus law policy scheme from the perspective of the tax canon, as it is recognized that canons of taxations are the tool for judging that make the tax system effective and functional. This is a preliminary study of tax omnibus law, as the omnibus law has only just been implemented in 2021. There is still no empirical literature on taxation omnibus law so this research examines tax incentives at a conceptual level.

The government does have the legal legitimacy to reform tax regulations in addressing national problems. However, this legitimacy does not always guarantee the acceptance of the tax community (taxpayers). The community will conduct an evaluation so that it determines the position of attitude, acceptance or rejection, and compliance with regulations, which is known as self assessment system (SAS) (Palil, 2010).

Theoretically, this research is expected to enrich the reference of tax incentives in the tax law omnibus policy scheme. In terms of policy, this study is intended to provide a discourse for tax authorities on the suitability of tax incentive policy packages based on good taxation principles (canon taxation). In practical terms, this research can increase the acceptance of the wider community that this tax incentive policy package benefits the national economy, especially in the era of the Covid pandemic.

The research findings are classified based on the themes (pillars) of the tax incentive policy scheme, namely to attract foreign investment, expand tax subjects and objects, increase voluntary compliance, create a climate of business justice, and tax facilities in tax regulations. Each theme will be discussed based on the suitability of the principle of canon taxation.

\section{Methods}

In general, qualitative studies are understood as a research method that assumes that reality is not sterile from political, economic, and social interests. This method tries to catalyze so that reality appears more as it is; that is, more natural. In more detail, qualitative studies aim to understand phenomena based on qualitative data such as words, language, actions, motivation, and perceptions (Moleong, 2014). Analysis of research data will follow the rules that combine literature insight with the scientific insight of the researcher. As it is known, literature studies put the researcher as a research instrument.

Sources of data are obtained through literature studies, either through articles in journals, annual reports, online data sources, and newspapers. All the collected data is then analyzed as adapts from Febriana (2018) through several stages, including data reduction, verification, and 
conclusions. The analysis was carried out using an interactive analysis model, which is a series of interrelated relationships since the study was designed, verified, and concluded.

Using comparative techniques, namely examining the tax incentive aspects of the taxation omnibus law on 4 (four) main aspects of the canon taxation, as proposed by Adam Smith, the current research aims to describe the principles of good taxation in the tax omnibus law. So, the tax omnibus law in this study is the object of analysis or study. More specifically, this study develops insights based on classic works of literature on taxation principles. The research findings are classified based on the themes (pillars) of the tax incentive policy scheme, namely to attract foreign investment, expand tax subjects and objects, increase voluntary compliance, create a climate of business justice, and tax facilities in tax regulations. Each theme will be discussed based on the suitability of the principle of canon taxation

\section{Results and Discussion}

\section{First Principle: Tax Stimulus as Foreign} Investment Appeal

Tax incentives or tax stimuli are tax strategies provided to support foreign investment activities that meet certain requirements (Fletcher, 2002). This stimulus can be in the form of tax holidays, customs policies, investment policies, and others (Revilla, 2016). It is well known that the war on tax rates to attract foreign investment began after the economic crisis in 1997 (Madiès \& Dethier, 2012).

During this pandemic, the government has released a tax incentive policy to attract foreign investment by setting an adjustment in the corporate tax rate from $25 \%$ to $22 \%$ in 2021 and 2022 and removing taxes on dividends (domestic and foreign). Furthermore, companies that have just gone public are given a lower rate of $3 \%$, valid for 5 years. This policy can be seen to be in line with the principle of equity, which requires fairness in the tax system, namely that taxes must be collected fairly in accordance with the economic capacity of the taxpayer. The establishment of corporate tax to gradually decrease in 2021 and 2022 at a rate of $22 \%$ will lead to increased productivity and an increase in the workforce.

The principle of equity can be vertical or horizontal justice (Carnaghan et al., 2004). Horizontal justice requires the tax system to apply the same criteria to taxpayers. The $22 \%$ criterion can meet the horizontal justice principle because it will be the rate for all corporate taxpayers.

The principle of vertical equity is how taxes are imposed on different levels of income. This principle considers the relative economic capacity of each taxpayer to pay. With the principle of vertical equity, high-income groups will pay more tax than lower-income groups. A rate of $22 \%$ for companies with high income will flow higher tax than for companies with lower income.

However, the economic slowdown as a result of the covid pandemic will naturally reduce the capacity on the supply and demand sides. Large-scale social restrictions and abnormalities in the national and international supply chains will have a significant impact on liquidity (cash flow). Meanwhile, the demand side is faced with a decline in income and even threats of layoffs (termination of employment) (Kristiaji, 2020). Thus, tax reduction cannot be enjoyed by taxpayers.

To attract foreign investment, the tax relaxation policy is clearly not being realized by 2020. Large-scale social restrictions at home and international traffic naturally halt the flow of new foreign investment that the government hopes for. On the empirical side, several studies have rejected tax rates as a determinant of investment decisions (Morisset, 2003; Revilla, 2016). The French car group company, PSA Citroën, for example, chose Trnava in Slovakia as an investment location in Central Europe and refused investment offers in Poland and Hungary even though the tax rates in 
these three countries were the same (Madiès \& Dethier, 2012). Likewise, BMW chose Germany as the location for its new factory, and the Ford company chose the Philippines, even though other countries also offer competitive and attractive taxes (Madiès \& Dethier, 2012).

The tax incentive policy is less attractive to foreign investors. They need more information on effective tax rates (ETR) (Madiès \& Dethier, 2012) for the benefit of business planning. However, ETR information is often not available, even though ETR is considered more appropriate to be used to compare tax rates between countries.

The government also encourages companies to go public companies by issuing a $3 \%$ lower tax policy and is valid for 5 years for companies that have just gone public. This principle reflects the canon of equity and certainty. Go public companies must be supported by a lower tax scheme related to the amount of financial capacity needed for this company to develop. The principle of certainty is related to the clarity of tax rights and obligations. Tax system certainty is one aspect of business planning. Every business has a long-term plan, including the tax burden that must be paid.

Companies that have just gone public require prediction of long-term business planning, including tax burden. The time limit of 5 years is a certain aspect that makes it easier for companies that have just gone public to do their business planning. A clear and predictable tax system is an important aspect in attracting investment because it will facilitate business planning and budgets. Changes in the tax system caused by changes in local economic activities must be predictable by business actors.

Smith's extreme view is to criticize the tax on profits (Fugaru, 2015). Taxes of this kind are thought to hijack resources for value creation activities and, in turn, cause an increase in the price of goods. In essence, when the traffic of capital between countries can be moved easily, an increase in tax rates will reduce net income, thus encouraging investors to shift their capital to other countries (Madiès \& Dethier, 2012).

Next is related to the territorial system for foreign income. The tax write-off facility is not imposed on dividends from abroad, which are reinvested in Indonesia. The write-off of income tax on dividends is an instrument to increase investment attractiveness (Hadari, 1990). This policy can change the structure of domestic company funding to be healthier because the dividends earned will be encouraged to be reinvested so that it can guarantee a turnover of capital in the country. This system indirectly eliminates double taxation, namely taxation of profits at the corporate level and taxation of dividends on the side of investors (Harris, 2013). Several countries have implemented a re-investment system in part or in full (Cnossen, 2015). Exemption from dividend tax that is balanced with the obligation to invest domestically so as to minimize tax saving (Darussalam et al., 2019).

\section{Second Principle: Determining Criteria for Individual Tax Payer}

The second pillar is related to the determination of criteria for the individual tax payer, namely foreigners who work in Indonesia for more than 183 days and are classified as domestic tax payer. Conversely, Indonesian citizens who have lived abroad for over 183 days are classified as foreign tax payer.

In this case, the tax is imposed on foreigners only on income earned in Indonesia. This policy is also a strategy to avoid double taxation so that tax avoidance loopholes can be minimized. This policy meets certainty principles relating to the clarity of tax rights and obligations by taxpayers. Clarity of criteria for domestic and foreign tax subjects will encourage tax avoidance behavior due to double taxation. 


\section{Third Principle: Tax Relaxation to Improve Voluntary Compliance}

The third pillar is a scheme to increase voluntary compliance with a series of policies to relax the right to credit input taxes for taxable entrepreneurs, a scheme of rearranging tax, excise, and customs administration sanctions. A number of tax stimuli were launched by the government in the context of handling emergencies during the pandemic, including by giving the Minister of Finance the authority to facilitate import duties in the form of relief and exemptions. This relaxation is aimed at handling and restoring and strengthening the national economy. Several other policies are related to the provision of tax incentives for taxpayers affected by the pandemic, namely Income tax 21 DTP incentives, withholding tax under article 22 of imports transaction, reduced installments of Income tax article 25, and import VAT.

In the VAT scheme, the input tax can be credited according to the proof of invoice owned and a refund can be requested at the end of the financial year. Allowances on the VAT aspect can lead to voluntary compliance or even to cooperative compliance.

Tax relaxation in a pandemic situation in line with the principle of convenience demands simplicity and convenience in fulfilling tax obligations. Calculation and fulfillment of tax administration obligations must be easily carried out by taxpayers. This way, the taxes will be easy to comply with. Tax compliance will arise from the ease with which taxpayers deal with taxes. So, convenience and comfort will increase tax compliance. On the other hand, the complexity of the tax system makes taxpayers lazy to deal with taxes so that they will avoid taxes. A good tax system suggests simplicity and ease of understanding by all taxpayers. It must be ensured that taxes are not complex to calculate or pay and report.

Regarding tax incentives for import activities, which are rolled out to 102 types of businesses in 19 sectors, the sector has experienced import difficulties since the pandemic situation in China. The form of the incentive is the exemption of import duties from April to September 2020 (Sari, 2020). Several studies, as explained by Smith, rejected customs duties because it would distort trade, that is impacts rising commodity prices, thereby reducing consumption and providing an opening for smuggling (Fugaru, 2015). This stimulus will, of course, in addition to saving national interests, also encourage a symbiosis of mutualism between the tax authorities and taxpayers, especially entrepreneurs (individual taxpayers). It is understood that personal taxpayers are more stable against crisis patterns. This character is not owned by corporate taxpayers who are sensitive to economic shocks.

The design of using interest rates as a reference for determining tax sanctions so that the number of sanctions can change depending on the size of the prevailing interest rates. This format can be viewed as a change in the interest sanction rate scheme from a fixed rate scheme to a flexible rate scheme, with reference to market interest rates. This scheme is a fairly ideal formula (Designing Interest and Tax Penalty Regimes, 2019) aimed at safeguarding state revenues and as a means of educating taxpayers so they are not late in carrying out tax obligations. However, it must be considered in other aspects regarding how much sanctions must be paid to use noncompliant taxpayers as an incentive to delay payments. Next, rearranging tax sanctions with reference to interest rates is intended to enforce the proportion of sanctions that must be received by taxpayers in line with the degree of error.

\section{Fourth Principle: A Climate Justice in Seeking}

The fourth pillar is creating a climate of business justice, namely a tax policy for electronic transactions in Indonesia and imposing a tax on the income of foreign tax subjects related to 
electronic transactions through the expansion of the Permanent Establishment (PE) criteria. The government appointed an electronic transaction platform to collect VAT.

The principle of equity requires justice in the tax system, namely that taxes must be collected fairly in accordance with the economic capacity of the taxpayer. The principle of equity can be vertical or horizontal justice (Carnaghan et al., 2004). Horizontal justice requires the tax system to apply the same criteria to taxpayers. Sales tax must be imposed on all buyers, both conventional and electronic (digital) transactions. This means that the state does not discriminate against taxpayers; all taxpayers who meet the criteria for earning income in Indonesia must be taxed regardless of the media used to obtain the income.

Requiring platforms (foreign suppliers) to collect, deposit, and report VAT on every electronic transaction means requiring foreign tax subjects to register as taxable entrepreneurs and collect VAT. This forces every platform (foreign supplier) to understand the tax regulations of each country unless the tax authorities offer simplification or ease of registration to encourage compliance. Foreign suppliers can also appoint representatives in Indonesia to collect, deposit, and report VAT on behalf of foreign tax subjects.

The complexity of registration rules and tax regimes can increase compliance costs. This contradicts the principle of efficiency which requires that the goal of optimizing state revenue can be achieved by stimulating investment. The complexity of the registration procedure will discourage foreign suppliers from serving consumers in these jurisdictions. Taxes will only be efficient if they are able to distort the administration of business processes because this will be a reason for taxpayers to avoid taxes (Kabinga, 2016).

Changing tax services to digital services can lead to cooperative compliance. Taxpayers do not need to come to the tax office to carry out their tax obligations so that they can be more efficient, effective, and fast. Eliminating direct interaction with the tax authorities is the simplicity of tax administration. This can further ensure transparency, cost and time efficiency, and certainty so that it is expected to create a symbiosis of mutualism between taxpayers and tax authorities and further encourage cooperative compliance and increase the tax ratio. In other words, the ease of taxation realized by digitizing tax services guarantees more tax compliance than the old, less effective methods.

In short, the digital tax service still demands convenience aspects. The complexity of the tax system will be a reason for taxpayers to avoid tax obligations. In this context, the tax authorities are challenged to ensure that all taxpayers are technology literate so that there are no difficulties in accessing digital tax services. Of course, these new methods can still be implemented after the pandemic has passed.

\section{Fifth Principle: Placing Tax Facilities into Tax Laws}

The fifth principle regulates tax facilities. The government determines tax facilities with a tax holiday scheme, income tax facilities for special economic zones, super deduction, Income tax for state securities, and regional tax relief or exemption.

The principle of efficiency focuses on the efficiency of collecting and allocating and utilizing tax money for the welfare of the people. Taxes become efficient if the aim is to optimize state revenue through investment stimulus but in a cost-effective manner. Increased investment through taxes will broaden the tax base that can increase state revenue. It is said to be efficient if it is able to distort the administration of business processes because this will be an excuse for taxpayers to avoid taxes (Kabinga, 2016).

The tax holiday scheme for the pioneer industry is urgently needed for development 
and expansion. This type of industry should be supported by tax exemptions so that it can grow. This is evidenced by manufacturing companies in several countries that the tax holiday scheme is able to attract foreign investment, such as in Kenya (Thuita, 2017), Ireland, and The Caribbean (Morisset, 2003). On the other hand, tax holidays can be seen as a quite dangerous incentive because they can be used as a gap in transfer pricing. Companies can shift the production sector to the country with a tax holiday scheme (Madiès \& Dethier, 2012).

Likewise, the Income tax facility for special economic zones, which is usually intended for export activities, will encourage investment growth that can boost the country's economy, create jobs, and become a new tax base received from employee Income tax. This scheme has been implemented in Kenya, aimed at export destination companies, and has proven able to stimulate foreign investment (Fletcher, 2002). This mindset is in line with the tax function aimed at stimulating the potential entry of foreign investment aimed at exports. This role puts taxes to achieve economic goals.

With regard to regional tax incentives in the form of exemptions or relief in line with the principles of equity and efficiency, the stimulus of increasing economic activity in the regions through relief and reduction of local taxes can encourage or stimulate private investment in the regions (Sunarti, 2011). The principle of equity in relation to local tax incentives can be an instrument that can guarantee investment certainty in the regions so that it can encourage economic acceleration after a pandemic. Furthermore, local tax exemptions can lower the price of consumer goods in the regions, thereby increasing the purchasing power of the wider community, which was hampered by the pandemic. In this way, local taxes play a role in increasing regional competitiveness through public policies (tax incentives) to improve the welfare of people, especially those affected by the epidemic.
Regional autonomy can be utilized by local governments in managing local taxes for the purpose of curbing negative economic trends during a pandemic (Aničić et al., 2016), especially if synergizes with economic policy (Kalaš et al., 2018). Several studies have shown that loosening local taxes can actually increase the tax base and local revenues (Harefa, 2016). Local tax incentives are a stimulus to increase the productivity of goods and services. Tax incentives can play a role in increasing the economic sophistication of a country (Lapatinas et al., 2019). In other words, the modernization of a country's economy reflects the appropriate regional fiscal policies and tax structures.

Regional tax incentives are very appropriate to be launched in 2020, which is being hit nationally and internationally, thereby reducing people's purchasing power. Related to this principle, this tax incentive scheme is in line with the convenience aspect, namely that taxes must be collected at the right time and released at the right time. Associated with a decrease in people's purchasing power, the regional tax incentive policy fulfills the equity principle.

\section{Conclusion}

This research is a conceptual study to examine tax policy in the pandemic situation, with the perspective of equity, certainty, convenience, and efficiency. Based on the analysis of literature studies, this research yields several things, first the principle of equity is found in adjusting the corporate tax rate from $25 \%$ to $22 \%$ in 2021 and 2022 and eliminating taxes on dividends (domestic and foreign). The principle is found certainty in determining the criteria for individual tax subjects, namely for foreigners who work in Indonesia for more than 183 days are classified as domestic tax payer. Conversely, Indonesian citizens who have lived abroad for over 183 days are classified as foreign tax payer. In this case, the tax is imposed on foreigners only on income 
earned in Indonesia. This policy is also a strategy to avoid double taxation so that tax evasion loopholes can be minimized.

The principle found that inconvenience in local tax incentives can be an instrument that can guarantee investment certainty in the regions so that it can encourage economic acceleration after a pandemic. Furthermore, local tax exemptions can lower the price of consumer goods in the regions, thereby increasing the purchasing power of the wider community, which was hampered by the pandemic. In this way, local taxes play a role in increasing regional competitiveness through public policies (tax incentives) so as to improve the welfare of people, especially those affected by the epidemic. The principle of efficiency is found in the tax holiday scheme. This type of industry should be supported by tax exemptions so that it can grow.

In simple terms, tax facilities or incentives and their relation to good taxation principles are summarized as follows: first, increasing attractiveness of a foreign investment destination country. There are 6 (six) items to achieve this goal. The first is reducing the corporate income tax rate from $25 \%$ to $22 \%$. It fulfills the canon of equity; taxes are collected according to the economic capacity of the taxpayer as a result of the Covid-19 pandemic. The next is removing the tax of dividends as representation on the canon of certainty, which has an impact on avoiding double taxation. The next is adjusting the income tax rate of tax article 26; this corresponds to the canon of certainty, which has an impact on avoiding double taxation. The next is the tax holiday scheme, local tax facility, and super duduction facility. It relates to the canon of equity and support for industrial growth and investment, including investment in the region.

Second, increasing equality and justice in business by imposing taxes on digital transactions of overseas sellers and marketplaces. It fulfills the canon of equity; taxes are imposed on all sellers with both conventional sales and digital-based sales. The next is local tax rationalization. It refers to the canon of equity, to increase investment attractiveness in the region. The next is adjusting of excisable goods. It represents the canon of equity, to increase people's purchasing power during a pandemic.

Third, to improve the quality of the human resources by imposing tax on foreign workers. It fulfills the canon of equity; that is, increasing business equity. Fourth, encouraging voluntary tax compliance by implementing VAT relaxation and determining the interest rate for tax sanctions. These refer to the canon of convenience, which requires easy input tax crediting and refund facilities, and also refer to the canon of equity, associating sanctions with the degree of tax negligence.

This study has limitations regarding findings that are only based on a review of the literature and have not been tested empirically. Future research needs to proceed empirically.

\section{References}

Aničić, J., Jelić, M., \& Đurović, J. M. (2016). Local Tax Policy in the Function of Development of Municipalities in Serbia. Procedia - Social and Behavioral Sciences, 221, 262-269. https:// doi.org/10.1016/j.sbspro.2016.05.114

Boly, A., Coulibaly, S., \& Kéré, E. N. (2019). Tax Policy, Foreign Direct Investment and Spillover Effects (310). https://www.afdb. org/en/documents/publications/ workingpaper-series/

Carnaghan, C., Downer, P., Klassen, K., \& Pittman, J. (2004). E-Commerce and Tax Planning: Canadian Experiences. Canadian Accounting Perspectives, 3(2), 261-287. https://doi. org/10.1506/V82X-X152-PND1-ABHE

Cnossen, S. (2015). What Kind of Corporation Tax Regime? Sijbren Cnossen. Osgoode Hall Law Journal, 52(2), 513-551.

Darussalam, D., Kristiaji, B. B., \& Yustisia, D. (2019). Prospek Pajak Warisan di Indonesia 
(DDTC Working Paper 2019; DDTC Working Paper 2019). https://ddtc.co.id/id/riset/ publikasi/working-paper/prospek-pajakwarisan-di-indonesia/\#.Xo_XUP0zbIU

Daude, C., Gutierrez, H., \& Melguizo, A. (2017). Doctoring the ball: The political economy of tax incentives for investment in the Dominican Republic. Journal of Economic Studies, 44(1), 2-23. https://doi. org/10.1108/JES-05-2015-0090

Directorate General of Taxes, D. (2020a). Direktorat Jenderal Pajak Tanggap COVID-19. Direktorat Jenderal Pajak, DJP. https://www.pajak. go.id/covid19

Directorate General of Taxes, D. (2020b). Jaga Ekonomi Indonesia, Pemerintah Berharap Omnibus Law Perpajakan dapat Segera Diundangkan. Direktorat Jenderal Pajak, DJP. https://www.pajak.go.id/id/siaranpers/jaga-ekonomi-indonesia-pemerintahberharap-omnibus-law-perpajakan-dapatsegera

Enache, C., Asen, E., \& Bunn, D. (2020). Tracking Economic Relief Plans Around the World during the Coronavirus Outbreak. Tax Foundation. https://taxfoundation. org/coronavirus-country-by-countryresponses/

Febriana, R. (2018). Studi Kepustakaan dalam Disiplin Ilmu Akuntansi. In Metode Penelitian (pp. 92-107). Universitas Gunadarma.

Fletcher, K. (2002). Tax Incentives in Cambodia, Lao PDR, and Vietnam. IMF Conference on Foreign Direct Investment: Opportunities and Challenges for Cambodia, Lao PDR and Vietnam. https://www.imf.org/external/ pubs/ft/seminar/2002/fdi/ eng/pdf/ fletcher.pdf

Fugaru, A. (2015). The Fiscal Tradition in Europa - A Hindrance to Achieving the Fiscal Union? Procedia Economics and Finance, 22, 412-421. https://doi.org/10.1016/S22125671(15)00317-2
Hadari, Y. (1990). The Role of Tax Incentives in Attracting Foreign Investments in Selected Developing Countries and the Desirable Policy. The International Lawyer, 24(1).

Harefa, M. (2016). Efektivitas Pemungutan Pajak PBB P2 Oleh Pemerintah Kota Makasar dan Sumbangannya Terhadap Pendapatan Daerah. Jurnal Ekonomi Dan Kebijakan Publik, 7(1), 67. https://doi.org/10.22212/ jekp.v7i1.414

Harris, P. (2013). Corporate Tax Law. Cambridge University Press. https://doi.org/10.1017/ CB09781139519922

Kabinga, M. (2016). Principles of Taxation. Tax Justice \& Poverty.

Kalaš, B., Mirović, V., \& Milenković, N. (2018). The Relationship between Taxes and Economic Growth: Evidence from Serbia and Croatia. The European Journal of Applied Economics, 15(2), 17-28. https://doi.org/10.5937/ EJAE15-18056

KPMG, K. (2020). Germany: Tax relief measures in response to coronavirus (COVID-19). KPMG. https://home.kpmg/us/en/home/ insights/2020/03/tnf-germany-tax-reliefresponse-coronavirus.html

Kristiaji, B. B. (2020). Pandemi Covid-19 dan 9 Prediksi Pajak di Masa Mendatang. DDTCNews. https://news.ddtc.co.id/ pandemi-covid-19-dan-9-prediksi-pajakdi-masa-mendatang-20415?page_y=600

Lapatinas, A., Kyriakou, A., \& Garas, A. (2019). Taxation and economic sophistication: Evidence from OECD countries. PLOS ONE, 14(3), e0213498. https://doi.org/10.1371/ journal.pone.0213498

Li, Quan. (2006). Democracy, Autocracy, and Tax Incentives to Foreign Direct Investors: A Cross-National Analysis. The Journal of Politics, 68(1), 62-74. https://doi. org/10.1111/j.1468-2508.2006.00370.x

Li, Qun. (2008). Tax Incentive Policies for ForeignInvested Enterprises in China and their 
Influence on Foreign Investment. Revenue Law Journal, 18(1).

Madiès, T., \& Dethier, J.-J. (2012). Fiscal Competition in Developing Countries: a Survey of the Theoretical and Empirical Literature.Journal of International Commerce, Economics and Policy, 03(02), https://doi.org/10.1142/ S1793993312500135

Megersa, K. (2019). Review of tax incentives and their impacts in Asia.

Moleong, L. (2014). Metode Penelitian Kualitatif (Edisi Revi). PT Remaja Rosdakarya.

Morisset, J. (2003). Tax Incentives : Using Tax Incentives to Attract Foreign Direct Investment. Viewpoint: Public Policy for the Private Sector, 253. https://openknowledge. worldbank.org/handle/10986/11325

Palil, M. R. (2010). Tax Knowledge and Tax Compliance Determinants in Self-Assessment System in Malaysia [The University of Birmingham]. https://etheses.bham. ac.uk//id/eprint/1040/1/Palil10PhD.pdf

Parys, S. Van. (2012). The effectiveness of tax incentives in attracting investment: evidence from developing countries. Reflets et Perspectives de La Vie Économique, LI(3), 129. https://doi.org/10.3917/ rpve.513.0129
Revilla, M. L. D. (2016). Cross-country econometric study on the impact of fiscal incentives on FDI. http://hdl.handle.net/10419/173538

Sari, R. (2020). Urgensi Stimulus Perpajakan Sektor Manufaktur Akibat Pandemi Covid-19. In Puslit (Ed.), Info Singkat (Vol XII No). Pusat Penelitian Badan Keahlian DPR RI.

Smith, A. (1776). An Inquiry into the Nature and Causes of the. Wealth of Nations (S. M. Soares (ed.); 2007th ed.). Metalibri Digital.

Stausholm, S. N. (2017). Rise of ineffective incentives: New empirical evidence on tax holidays in developing countries. SocArXiv. https://doi.org/https://doi.org/10.31235/ osf.io/4sn3k

Sunarti, E. S. (2011). Pajak Melindungi Ketersediaan Air Tanah. Jurnal Legislasi Indonesia, 8(1), 117-138.

Thuita, G. W. (2017). An Investigation of the Effect of Tax Incentives on the FDIs: A Case of EPZs in Athi River Kenya. Ournal of Accounting, Finance and Auditing Studies, 3(1), 17-36

Designing Interest and Tax Penalty Regimes, Pub. L. No. IMF Tax Law Technical Note 19/01 (2019).

Wiedemann, V., \& Finke, K. (2015). Taxing investments in the Asia-Pacific region: The importance of cross-border taxation and tax incentives. http://ftp.zew.de/pub/zewdocs/dp/dp15014.pdf 